\title{
KOLASE BAHAN ALAM
}

\author{
Siti Nurkhasanah \\ FKIP, Universitas PGRI Adi Buana Surabaya, (Siti Nurkhasanah) \\ @mail : liviauliv@gmail.com
}

\begin{abstract}
The implementation of KKN PPM is implemented, such as training activities collage of natural materials in kindergarten Aisyiyah Bustanul Atfal, the trainees are students-students with a number of 31 children. the location of the training activities carried out at the Village Hall Dermo, District Benjeng, Gresik. Selection of the type of skill is partly due to the activities collage of natural materials still little known to the child, even many of the students lack of interest dents collage collage mainly natural materials, and a lack of impetus from educational institutions and parents so as to enable the development of activities of collage of natural materials in order to can create learning activities that are creative and innovative. The implementation of the PPM service learning activities are more focused on aspects of practice rather than theory, with a ratio of $80 \%$ practical and $20 \%$ theory, so students can further dents to imagine in following the activities collage of natural materials and provide new experiences with activities directly with media provided.
\end{abstract}

keywords: collage, material, natural

\section{PENDAHULUAN}

Kegiatan KKN (Kuliah Kerja Nyata) merupakan wujudnya tapelaksanaan tentang pengabdian kepada masyarakat yang merupakan suatu kebijakan pemerintah. Hal ini dapat diperlihatkan dari beberapa faktor yang digunakan sebagai landasan-landasan yang telah ditetapkan pemerintah sebagai program nasional.

Dalam Kreasativitas kolase bahan alam ini bertujuan untuk meningkatkan kreativitas anak usia dini yang ada di TK Aisyiyah Bustanul Atfal di Desa Dermo Kecamatan Benjeng Kabupaten Gresik .dalam kegiatan lomba kolase bahan alam. Di jaman modern banyak orang tua yang memberikan fasilitas lebih untuk menunjang perkembangan anak, namun terkadang orang tua juga kurang faham bagaimana memberikan media untuk bermain. Misalnya media elektronik seperti handphone, tablet ataupun yang lainnya. Hal ini memberikan dampak kurang baik bagi anak karena anak kurang bersosialisasi dengan lingkungan sekitar dan kreativitas anak menjadi kurang berkembang. Dengan kegiatan yang menggunakan media nyata seperti halnya kolase bahan alam, secara tidak langsung anak belajar berbagai macam seperti, nama- nama biji- bijian dan mengekspresikan diri melalui kegiatan yang dilakukannya,

Dalam bidang seni barang bekas seperti majalah lama, Koran bekas, pakaian, kardus, kaleng, plastik kemasan dan daun-daun kering dapat digunakan untuk menghasilkan bermacam kreasi yang unik salah satunya melalui kolase. Menurut $\mathrm{M}$. Saleh Kasim (1981:10) kolase adalah menggambar dengan teknik tempelan. Menurut Muharam E (1992:84) menyatakan bahwa kolase adalah teknik melukis dan mempergunakan warna-warna kepingan batu, kaca, marmer, keramik, kayu, yang ditempelkan. Kolase merupakan bentuk gambar yang diwujudkan dengan menyusun kepingan berwarna yang diolesi lem kemudian ditempelkan pada bidang gambar. Menurut Budiono MA (2005:15) mengartikan "kolase sebagai komposisi artistik yang dibuat dari berbagai bahan yang ditempelkan pada permukaan gambar". Menurut Sunaryo A. (2002:89) menyatakan keterampilan kolase merupakan aktivitas yang penting dan kompleks. Menurut Susanto M. (2002:63) menyatakan bahwa kata kolase yang dalam bahasa Inggris disebut "collage" berasal dari kata "coller" dalam bahasa Perancis yang berarti "merekat". Selanjutnya kolase dipahami sebagai suatu teknik seni menempel berbagai macam materi selain cat, seperti kertas, kain, kaca, logam, kulit telur dan lain sebagainya kemudian dikombinasi dengan penggunaan cat (minyak) atau teknik lainnya. Berdasarkan beberapa pendapat diatas, dapat disimpulkan bahwa kolase adalah kegiatan menempel ke dalam bentuk gambar yang telah ditentukan.

Kegiatan kolase bahan alam membantu merangsang kemampuan motoric halus anak Keterampilan motorik halus didefinisikan sebagai keterampilan yang memerlukan kemampuan untuk mengkoordinasikan atau mengatur otot-Otot kecil atau halus. Gerakan motorik halus ini berkaitan dengan gerakan mata dan tangan yang efisien, dan tepat. Perkembangan motorik halus sangat penting bagi anak untuk persiapan menulis pada jenjang sekolah dasar dan dalam kegiatan sehari- hari anak seperti,mengancingkan baju, mengikat tali sepatu, dan memegang botol air minum. Tujuan kegiatan motorik halus 3 adalah menstimulasi perkembangan otot, sebagai modal dasar untuk menulis,mengenal warna atau bentuk, melatih gerakan otot jemari atau 
pergelangan tangan agar lentur, menyalurkan perasaan, menciptakan keindahan dalamimajinasi, dan kreatifitas anak dapat berkembang secara optimal.

Alat permainan kolase merupakan alat permainan edukatif dengan biayamurah dan bisa menggunakan bahan-bahan bekas dan bahan alam yangterdapat dilingkunagan sekitar anak. Alat permainan kolase ini tidak membahayakan bagi kesehatan anak karena bahan - bahan yang dipakai adalah bahan yang biasa digunakandan berada dilingkungan anak. Pembuatan permaian kolase ini memerlukan koordinasi dari mata dan tangan serta keterampilan anak dalam menempelkan bahan yang akan membantu menstimulus memampuan motorik halus anak usia dini.

Dalam pelaksanaan praktek lapangan ini memberikan kesempatan bagi siswa-siswi yang ada di TK Aisyiyah Bustanul Atfal di Desa Dermo Kecamatan Benjeng Kabupaten Gresik dengan memberikan ilmu dan pengalaman secara langsung yang telah diperoleh dari kegiatan ini sehingga kehadiran TK Aisyiyah Bustanul Atfal di Desa Dermo Kecamatan Benjeng Kabupaten Gresik.

Pada kesempatan ini kami selaku mahasiswa Universitas PGRI Adi Buana Surabaya yang sedang melakukan kegiatan KKN - PPM memfokuskan pada kegiatan Pembuatan Batik Jumput. Bahan yang kami gunakan dalam praktek ini yakni dengan bahan alam seperti biji- bijian Alasan menggunakan bahan alam karena bahan- bahan yang digunakan aman untuk anak dan mudah diperoleh dilingkungan sekitar desa Dermo Kecamatan Benjeng Kabupaten Gresik

\section{METODE}

Kegiatan dilaksanakan pada hari / tanggal yakni sabtu / 27 Febuari 2017 pukul 07.30 WIB - 10.00 WIB. Lokasi kegiatan ialah dib alai desa. Sasaran kegiatan ini ialah Siswa-siswi TK Aisyiyah Bustanul Atfal di Desa Dermo Kecamatan Benjeng Kabupaten Gresik.

Berikut adalah bahan yang digunakan untuk praktek pembuatan batik jumputan :

1. kacang hijau

2. kacang kedelai

3. jagung

4. beras

5. beras ketan

6. lem

Berikut adalah bahan yang dibutuhkan untuk praktek lomba kegiatan kolase bahan alam :

1. mangkok streofoam

2. cup

3. sendok

4. kertas bergambar

5. tisu basah

\section{6. tisu kering}

Rencana kegiatan ialah siswa- siswi mendapat penjelasan tentang tema yang terkait dengan kegiatan yang akan dilombakan, kemudian memperkenalkan kepada anak tetang kolase bahan alam yang menggunakan biji- bijian.memperkenalkan alat dan bahan yang akan digunakan anak seperti kertas dan lem. Dengan kemudian menjelaskan aturan bermain kepada siswa- siswai.dibutuhkan, Menjelaskan langkah-langkah pembuatan kolase bahan alam. Kemudian siswa- siswi diberikan alat beserta bahanbahan lainnya.

\section{HASIL DAN PEMBAHASAN}

Proses kreasi atau proses kreatif merupakan tahapan yang harus dilalui oleh seseorang dalam suatu karya seni yag dalam hal ini adalah kolase, mozaik, dan montase. Mulai dari proses memperoleh, dan menemukan sumber ilham atau inspirasi, gagasan hingga proses mewujudkan dalam karya kolase, mozaik, dan montase. Dalam hali ini impresi yang dirasakan, dipikirkan, dan dihayati oleh seseorang dituangkan sebagai ekspresi yang personal dalam wujud karya kolase, mozaik, dan montase. Kreasi dalam pembuatan karya tersebut melalui tahapan-tahapan, yaitu: tahap rasa, tahap karsa, tahap cipta dan tahap karya. Tahapan dari yang bersifat rasa dan karsa sampai ke bentuk yang bersifat fisikal.

Tahapan rasa, Merupakan proses psikologi yang terjadi dalam diri seseorang pada saat stimulus ditangkap oleh seseorang melalui fungsi indrawi. Hal ini melalui proses pengamata, pemusatan perhatian dan kesadaran estetika terhadap objek yang kemudian diapresiasikan sehingga memperoleh rangsangan yang bersifat internal yang berasal dari luar dirinya. Stimulus yang berupa rangsangan ini menimbulkan semacam getaran atau dalam istilahnya Cicelia "sensasi indrawi" (2006). Sensasi ini pada aealnya belum memiliki makna, tetapi lama kelamaan dapat menjadi bermakna karena bertambahnya pengalaman personal yang selalu berdekatan dengan seni.

Selanjutnya proses mempersepsi, proses ini merupakan lanjtan dari proses rasa sensasi, lalu setelah dirasakan akan menimbulkan kesan yang memiliki makna tertentu pada dirinya. Dalam proses pencerapan ini terjadilah asosiasi dan mekanisme kemampuan (intelektual) yang lain, yaitu: kemampuan membedakan (diferensiasi), kemampuan membandingkan (komparasi). Kemampuan persamaan (analogi) yang akhirnya dapat menyimpulkan (sintesis). Dan kesemuanya ini menghasilkan pengalaman bermakna yang lebih luas dari sebelumnya. Merupakan proses psikologi yang terjadi pada diri seseorang yang memiliki kaitan dengan rangkaian proses merenungkan, proses menanggapi, proses menikmati kesan pada saat akan menuangkan gagasan dalam berkarya. 
Proses merenungkan, merupakan proses dalam membangun tanggapan-tanggapan yang mendalam terhadap sensasi-sensasi indrawi yang sering disebut pula sebagai kesan (impresi). Adapun tanggapan atau kesan (impersi) yang ada kaitannya dengan pemikiran secara sadar disebut interprestasi, sedangkan tanggapan-tanggapan atau kesan yang ada hubungannya dengan perasaan seseorang disebut emosi.

Untuk merespon atau menanggapi kesan yang lebih mendalam dibutuhkan fungsi aktif intelektual yang kemudian dipadukan dengan emosi. Dari perpaduan fungsi-fungsi ini akan membentuk pemahaman yang dalam mengenai apa yang telah dirasakan oleh seseorang dalam proses menikmati suatu seni. Emosi estetis adalah emosi timbul karena impersi (kesan) yang mendalam terhadap perasaan pada waktu terjadi sensasi dalam proses penikmatan seni. Maka tanpa faktor impresi, suatu proses penikmatan seni tidak dapat tercapai.

Rasa dan karsa merupakan rangkaian proses yang saling berhubungan dan merupakan tahapan yang sangat penting., karena proses ini sebagai sumber munculnya gagasan atau inspirasi yang kemudian diekspresikan. Gagasan atau inspirasi merupakan sumber untuk prosesnya kreasi yang kemudian dimunculkan berupa ungkapan secara spontan dan melalui proses pencarian/terencana tentang ide dengan diupayakan secara sengaja. Jadi, pemunculan gagasan atau inspirasi dapat dengan cara spontan dan secara sengaja (terencana).

Mencipta, maksudnya merupakan proses memanifestasikan atau menghadirkan sesuatu gagasan atau imajinasi seni menjadi bentuk karya fisik berupa karya dua dimensional. Gagasan atau imajinasi yang berupa rancangan pikiran abstrak kemudian melalui proses pemfisikan menjadi bentuk fisik yang bersifat indrawi. Kesan yang dirasakan dan dipersepsikan oleh seseorang pada saat penikmatan seni kemudian diolah dalam proses fisik menjadi bentuk fisik.

Karya merupakan proses dari gagasan atau ide dan berkembang menjadi fisik (cipta) yang ppada akhirnya terbentuklah "karya seni rupa". Seperti kolase, mozaik, dan montase. Hasil karya penaplikasiannya mengikuti kaidah-kaidah estetika namun bentuk fisiknya tergantung dari teknik (imitasi dan modifikasi) yang digunakan.

Bentuk imitasi adalah meniru hal-hal yang telah ada, sehingga dalam berkarya berusaha menciptakan karya sesuai dengan bentuk yang sebenarnya. Bentuk modifikasi dibagi beberapa cara, yaitu: stilisasi, adalah mengubah bentuk dengan cara deformasi adalh mengubah bentuk dengan cara menyederhanakan bentuk struktur bentuk sebuah objek estetis, distori adalah proses perubahan bentuk-bentuk dengan cara menghancurkan struktur bentuk sebuah objek estetis. Hal ini banyak terjadi pada pembuatan karya seni moozaik.

Anak harus diberikan stimulus estetis atau rangsangan berekspresi untuk mengungkapkan idenya kepada mereka yang belum mempunyai ide. Agar terarah dan mengerti rambu-rambu tentang kolase, mozaik, dan montase, maka perlu diberikan gambaran secara sederhana tentang batasan-batasan dan media bahan dan alat.

Bahan dan Alat, Anak Usia Dini imajinasinya masih murni, sehingga proses pengungkapan imajinasi mereka menjadi sebuah karya rupa seperti halnya mereka sedang bermain Dalam penggunaan alat harus dipertimbangkan segi keamanannya, karena tidak jarang pada anak usia dini dalam kegiatan pembelajaran, apalagi kegiatan tentang seni rupa maka anak-anak dalam belajarnya didominasi oleh bermain yang sering mengarah kepada bercanda

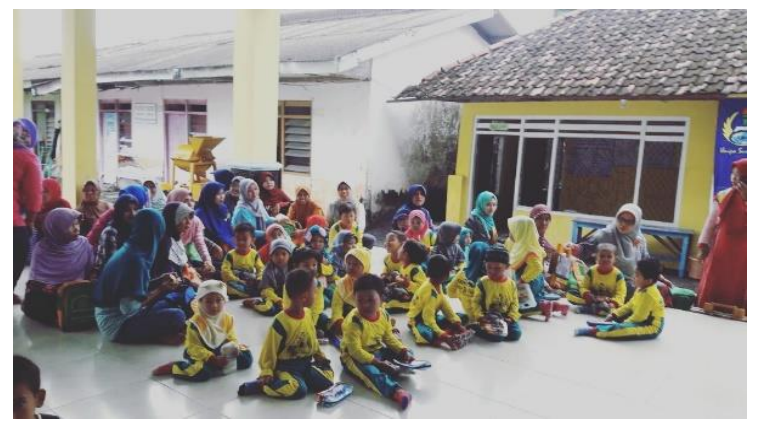

Siswa-siswi TK Aisyiyah Bustanul Atfal di Desa Dermo Kecamatan Benjeng Kabupaten Gresik diberikan penjelasan mengenai bahan, alat dan cara membuat kolase bahan alam. Siswa- siswi langsung praktek untuk membuat kolase bahan alam dengan media yang sudah disediakan.

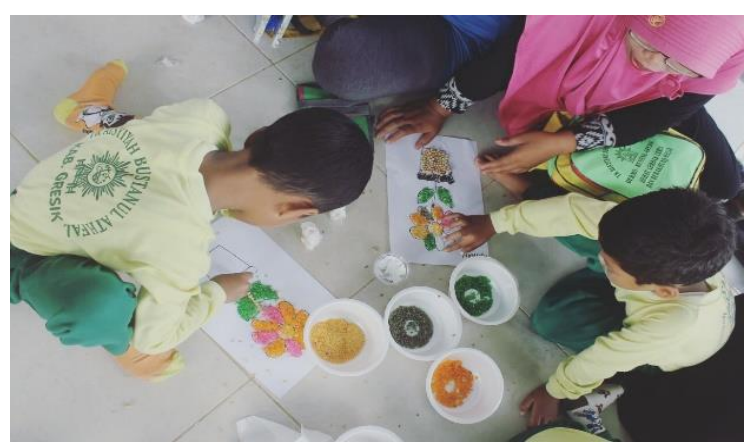

Menempel satu persatu bjii bjian mulai dari jagung yang di temple pada kelopak bunga,selain jagung anak- anak juga menggunakan beras yang berwarna- warni untuk kelopak bunga, anak- anak sangat berantusias dalam mengikuti kegiatan lomba kolase bahan alam mini. 


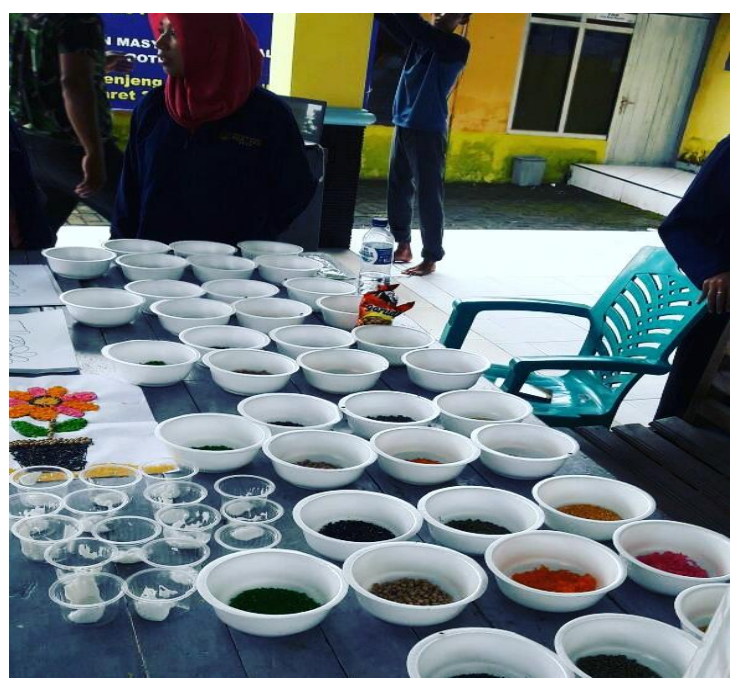

Selain menempel pada kelopak bunga anakanak juga menempelkan biji- bijian seperti kedelai pada batang bunga, anak-anak banyak ynag menggunakan biji kedelai untk bagian batang karena mempunyai warna coklat seperti halnta pada batang bunga yang sebenarnya

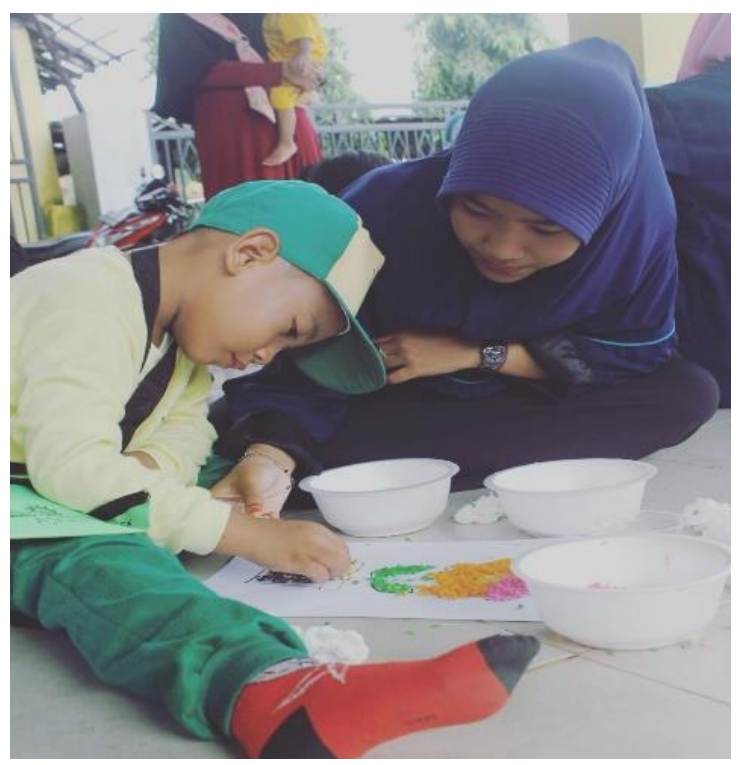

Kemudian anak- anak menempelkan biji beras ketan hitam sebagai tanah yang ada didalam pot, selain itu biji kacang hijaupun mereka gunakan untuk bagian daun. Kegiatan berlangsung dengan menyenangkan dan memberikan suasana yang ceria.

Hasil dari kegiatan ini bisa dijadikan kegiatan yang bisa diterapkan di lembaga pendidikan ataupun di rumah, dengan begitu anak akan tidak mudah bosan dengan pembelajaran yang monoton dan membuat anak tidak semangat.

Orang tua dan guru perlu memberikan kesempatan kepada anak agar anak dapat melatih kemampuan motorik halus nya dan mengembangkan imajinasi serta keterampilannya dengan memberikan kesempatan, anak akan lebih termotivasi dalam mengembangkan kemampuannya. Anak belajar melalui bermain dan anak mengenal banyak hal- hal baru dari lingkungannya. Selain itu pemanfaatan lahan yang ada disekeliling sekolah sangat penting untuk pembelajaran anak, anak- anak akan lebih senang dengan kegiatan yang dilakukan diluar sekolah misalkan dihalaman sekolah Oleh karena itu diperlukan lingkungan bermain yang kondusif yaitu lingkungan bermain yang dapat mengembangkan kemampuan mototirk halus anak dengan menyediakan sarana dan prasarana dalam lingkungan bermain tersebut. Sarana dan prasarana yang disediakan harus sesuai dengan usia anak dan tidak berbahaya. Dengan memberikan kesempatan anak akan dapatmengembangkan bakat dan potensi keterampilan motorik halusnya
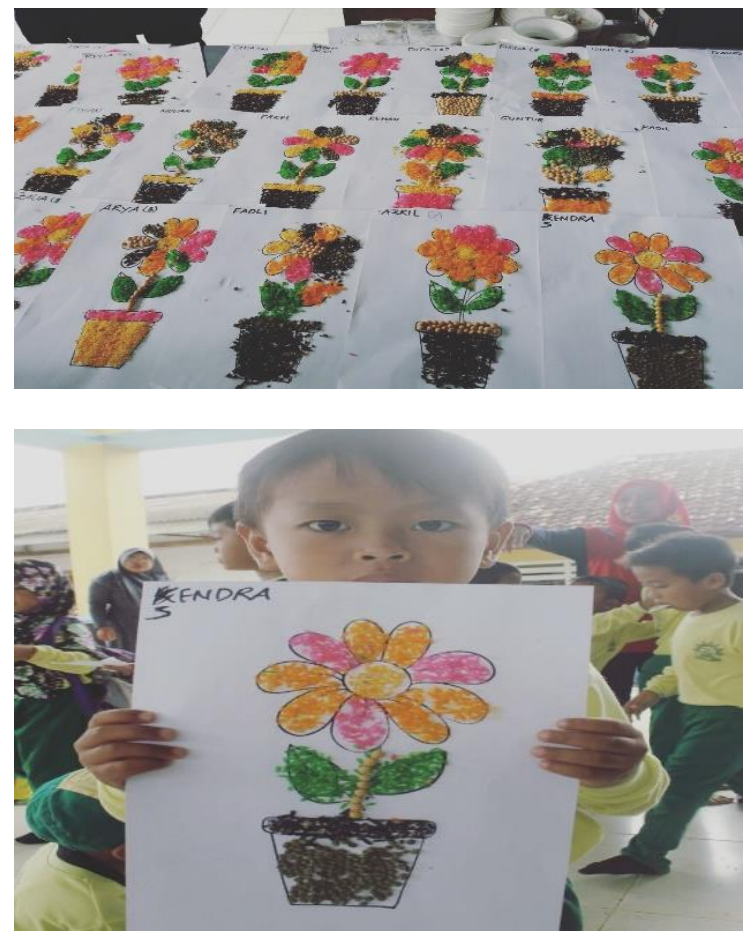

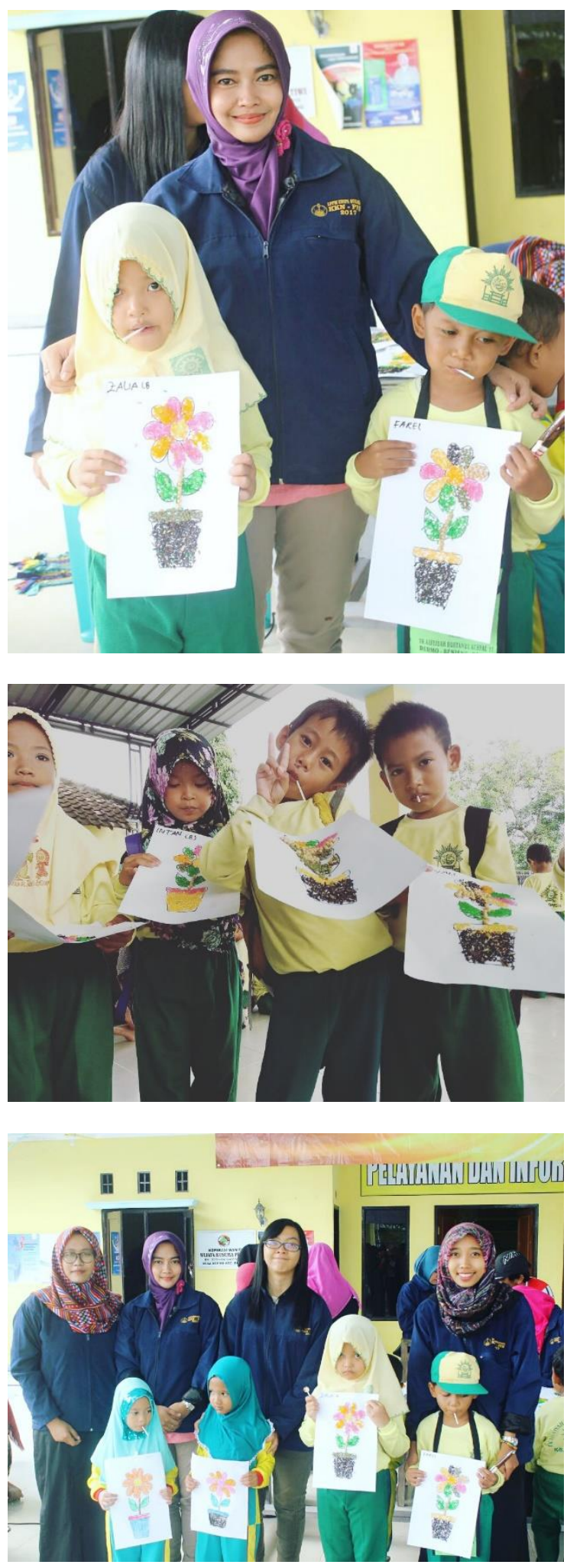

\section{SIMPULAN}

Progam kegiatan lomba kolase bahan alam dapat disimpulkan bahwa permainan kolase ini membantu merangsang perkembangan motoric halus anak dan membuat anak berimaginasi. Siswa- siswi senang setelah diberi kegiatan dengan bermain kolase. Terlihat pada saat anak melaksanakan kegiatan bermain kolase ana-anak terlihat senang dan gembira. Selain itu,membantu merangsang perkembangan fisik motoric lebiih baik, mengkoordinasikan gerakan mata dan tangannya, dan anak sudah dapat dengan baik menggerakan jarijemari tangannya saat menempel dan mengoleskan lem. Permainan kolase membantu dalam perkembangan motorik halus anak karena memiliki kegiatan- kegiatan yang dapat merangsang perkembangan motorik halus anak. Pada kolase dan kurang di perhatikan masyarakat. keberadaannya bahkan kurang dimengerti oleh masyarakat umum. Pemahaman tentang pengetahuan dan keterampilan kolase, montase merupakan hal yang sangat penting bagi seorang guru Taman Kanak-kanak, karena proses keterampilan kolase, bagi anak usia Taman Kanak-kanak merupakan kegiatan bermain sekaligus berseni dalam kegiatan anak.

\section{SARAN}

Pemahaman tentang pengetahuan dan keterampilan kolase, mozaik, dan montase merupakan hal yang sangat penting bagi seorang guru Taman Kanak-kanak, karena proses keterampilan kolase, mozaik, dan montase bagi anak usia Taman Kanak-kanak merupakan kegiatan bermain sekaligus berseni dalam kegiatan anak.

Maka dari itu sangat perlu menerapkan ketiga seni rupa tersebut bertujuan untuk mematangkan emosional bagi anak sehingga anak dapat memenuhi kebutuhan setiap fase perkembangan psikologi anak.

\section{REFEREN \\ SI}

Munandar, utami.2014. Pengembangan kreativitas anak berbakat. Jakarta: rineka cipta.

http://pembelajaranpendidikan.blogspot.co.id/2012/04/pengertiankolase.html Dakses pada tanggal 20 februari pukul 19.00 wib.

http://digilib.unila.ac.id/22908/3/SKRIPSI \%20TANPA\%20BAB\%20PEMBAHASAN.pd f di akses pada tanggal 20 Februari 2017 pukul 19.33 wib.

http://id.wikihow.com/Membuat-Kolase

http://misteriyan.blogspot.co.id/2016/02/pe ngertian-dan-cara-membuat-karya-seni.html diakses pada tanggal 22 Februari 2017.

http://melyloelhabox.blogspot.co.id/2012/1 0/kolase-mozaik-dan-montase.html diakses pada tanggal 23 februari 2017. 
ABADIMAS ADI BUANA Volume 02, Nomer 2, 01 Oktober 2017 